\title{
Molecular detection of Anaplasma phagocytophilum and Borrelia burgdorferi sensu lato genospecies in red foxes (Vulpes vulpes) from Romania
}

\author{
Mirabela Oana Dumitrache ${ }^{1}$, loana Adriana Matei ${ }^{1 *}$, Angela Monica lonică', Zsuzsa Kalmár ${ }^{1}$, Gianluca D’Amico ${ }^{1}$, \\ Sándor Sikó-Barabási ${ }^{2}$, Dan Traian Ionescu ${ }^{3}$, Călin Mircea Gherman ${ }^{1}$ and Andrei Daniel Mihalca
}

\begin{abstract}
Background: Red foxes (Vulpes vulpes) are one of the most widespread wild carnivores in the world, being recognized to harbor and transmit a wide range of vector-borne diseases. Anaplasma phagocytophilum and Borrelia burgdorferi sensu lato are zoonotic tick-borne pathogens causing emerging diseases. Wild animals play an essential role in the transmission of diseases and pathogens maintenance in nature. Epidemiological studies regarding the prevalence of tick-borne pathogens in red foxes are of public health importance, as they may successfully act as a pathogen transmission interface between wildlife, domestic animals and humans.

Findings: This study included 14 counties from Romania. A total number of 353 red foxes (Vulpes vulpes) were examined. Heart tissue samples were collected during necropsy and stored at $-20^{\circ} \mathrm{C}$. Genomic DNA extraction was performed and all samples were examined by polymerase chain reaction (PCR). Specific primers for $A$. phagocytophilum, A. platys, E. canis and Borrelia burgdorferi s.l. were used. Sequence analysis was performed (Macrogen Europe, Amsterdam) and obtained sequences are available at GenBank ${ }^{\mathrm{TM}}$. Out of the 353 samples, 9 (2.55 \%; $95 \%$ Cl: 1.25-4.96 \%) were positive for A. phagocytophilum. Positive animals originated from 5 counties. In total, 5 out of 353 heart tissue samples (1.42\%; $95 \%$ Cl: 0.52-3.47 \%) collected from red foxes were positive for $B$. burgdorferi s.l. Red foxes originated from 4 counties. None of the samples were positive for A. platys or $E$. canis. No co-infection with A. phagocytophilum and B. burgdorferi s.l. was found.
\end{abstract}

Conclusion: This first report of A. phagocytophilum and B. burgdorferi s.l. in red foxes from Romania suggests a limited role of foxes in the maintenance of the two related pathogens, but may represent a potential risk from a public health perspective.

Keywords: Red foxes, Anaplasma phagocytophilum, Borrelia burgdorferi, Tick-borne pathogens, Romania

\section{Findings}

\section{Background}

Red foxes are one of the most widespread wild carnivores in the world and one of the most adapted species to synanthropic ecosystems [1]. Foxes play an important role in the ecoepidemiology of several tick-borne pathogens, serving as reservoir hosts for zoonotic agents such

\footnotetext{
* Correspondence: matei.ioana@usamvcluj.ro

'Department of Parasitology and Parasitic Diseases, University of Agricultural Sciences and Veterinary Medicine Cluj-Napoca, Faculty of Veterinary

Medicine, Cluj-Napoca, Romania

Full list of author information is available at the end of the article
}

Borrelia burgdorferi [2] or as hosts for vectors [3] and contribute to disease dissemination to humans and domestic animals. Among these, Anaplasma phagocytophilum (the agent of human granulocytic anaplasmosis, canine and equine anaplasmosis and tick-borne fever in ruminants) and Borrelia burgdorferi s.l. (the agent of Lyme borreliosis) are both posing a real threat to public health. Due to increased awareness of medical personnel and improved diagnostic techniques, co-infections with more than one tick-borne pathogen are more commonly diagnosed in humans, animals and ticks. A. 
phagocytophilum and B. burgdorferi s.l. association has a particular clinical importance because co-infection intensifies the pathogenic process and increases the severity of the Lyme borreliosis as shown in animals [4]. Moreover, in Europe, the main vector for both pathogens is the same tick, Ixodes ricinus [5]. This species is widely distributed and has a low host-specificity being the dominant tick species in Romania [6].

Both transmission and maintenance of these pathogens in nature are following an enzootic lifecycle that involves ticks and a broad range of reservoir hosts [5] in which wildlife is an essential component [4]. Among wild canids, foxes are playing a key role, as they may act as an interface for pathogen transmission between wildlife, domestic animals and humans [1]. Despite this, little information is available on the occurrence of $A$. phagocytophilum and B. burgdorferi s.l. in red foxes in Europe.

The aim of this study was to detect the presence of $A$. phagocytophilum and B. burgdorferi s.l. in tissues of red foxes in Romania.

\section{Methods}

\section{Sample collection}

A total of 353 red foxes (Vulpes vulpes) from 14 Romanian counties (Fig. 1) were examined between October 2011 and May 2015. The animals were collected by the National Sanitary Veterinary Authority during the rabies monitoring program. All the animals negative for rabies were transported to our laboratory according to the current laws on dead animals transport and zoonotic risks. Heart tissue samples were collected during necropsy and stored at $-20{ }^{\circ} \mathrm{C}$ until further examination.

\section{DNA extraction}

Genomic DNA extraction was performed using ISOLATE II Genomic DNA Kit, Bioline, following the manufacturer's instructions. For each extraction procedure, negative controls (reaction mixture without tissue sample) were used in order to identify possible cross-contamination. DNA from a representative number of samples was quantitatively evaluated using Nanodrop ND-1000 spectrophotometer analyser.

\section{Polymerase chain reaction (PCR)}

All DNA samples were screened by PCR. The primers EHR16SD (5'-GGT ACCYACAGAAGAAGTCC-3') and EHR16SR (5'-TAGCACTCATCGTTTACAGC-3') were used, and the 16S rRNA gene (345-bp fragment) was amplified in order to detect Anaplasma, Ehrlichia, Neorickettsia, Wolbachia genera [7]. All positive samples were further examined using specific primers for A. phagocytophilum, $A$. platys and E. canis.

The presence of $A$. phagocytophilum was assessed by PCR using specific primers LA1/LA6 (forward primer: 5' GAGAGATGCTTATGGTAAGAC-3', reverse primer: 5' CGTTCAGCCATCATTGTGAC-3'), amplifying a 444-bp fragment of ankA gene [8]. The DNA extracted from the blood of a dog naturally infected with $A$. phagocytophilum (provided by IDEXX Germany) was used as positive control. A. platys DNA was amplified using specific primers EPLAT5 (5'-TTTGTCGTAGCT TGCTATGAT-3') and EPLAT3 (5'-CTTCTGTGGGTACCGTC-3') targeting a 359-bp fragment of the 16S rRNA gene [9]. Specific $E$. canis amplification was performed using the following primers CANIS (5'-CAATTATTTATAGCCTCTGGCTA TAGGA-3'), GA1UR (5'-GAGTTTGCCGGGACTTCT

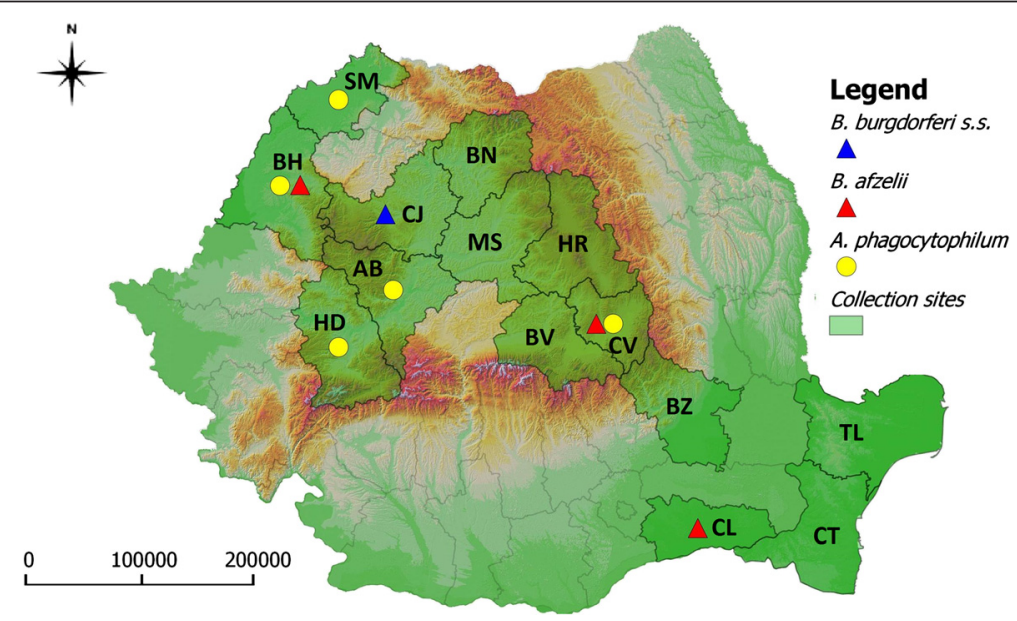

Fig. 1 Collection sites and geographical distribution of red fox positive samples for B. burgdorferi s.s., B. afzelii and A. phagocytophilum. AB=Alba; $\mathrm{BH}=$ Bihor; BN = Bistrița Năsăud; BV = Brașov; $\mathrm{BZ}=$ = Buzău; $\mathrm{CJ}=\mathrm{Cluj} ; \mathrm{CL}=$ Călărași; $\mathrm{CT}=$ = Constanța; $\mathrm{CV}=$ Covasna; $\mathrm{HD}=$ Hunedoara; HR = Harghita; MS = Mureș; SM = Satu Mare; $T L=$ Tulcea 
TCT-3'), targeting a 409-bp fragment of the $16 \mathrm{~S}$ rRNA gene [10]. DNA extracted from blood samples of dogs naturally infected with $A$. platys and $E$. canis were used as positive controls (provided by Prof. Harrus). The detection of $B$. burgdorferi s.l. was performed targeting the region of 5S-23S rRNA (rrf-rrl) intergenic spacer (IGS) in Bio-Rad T1000 Thermal Cycler, according to a previously described protocol [11]. For each PCR reaction, positive (B. burgdorferi s.l. culture strains) were used as positive control. In all cases, a reaction mix without DNA was used as negative control.

The PCR reaction was carried out in a final volume of $25 \mu$ using 2x Green DYE Master Mix (Rovalab GmBH). Amplicons were visualized by electrophoresis in a $1.5 \%$ agarose gel $\left(1 \times \mathrm{TAE}, \mathrm{pH}\right.$ 8.0) stained with $\mathrm{SYBR}^{\odot} \mathrm{Safe}$ DNA gel stain (Invitrogen).

\section{Sequencing}

For all A. phagocytophilum positive samples (targeting 16S rRNA gene) and For B. burgdorferi s.l. positive samples, PCR products were purified using QIAquick PCR Purification Kit (QIAGEN). Sequence analysis was performed (Macrogen Europe, Amsterdam) and the sequences were compared to those available in GenBank ${ }^{\text {TM }}$ dataset by Basic Local Alignment Tool (BLAST) analysis.

Sequences were submitted to the GenBank ${ }^{\mathrm{TM}}$ under the following accession numbers: KT351866, KT351867 and KT751324.

\section{Statistical analysis and mapping}

Statistical analysis of the results, prevalence of pathogens, its $95 \%$ confidence interval (95\% CI) and $p$ value, were performed using the EpiInfo 2000 software (CDC, USA).

The map including collection sites and positive counties for A. phagocytophilum and B. burgdorferi genospecies was generated using QGIS software.

\section{Ethics statement}

All aspects of sample collections were carried out in the framework of the disease control activities implemented and approved by the Ministry of Health and Ministry of Agriculture and Rural Development and adopted by regional and local administrative and veterinary and health authorities.

\section{Results}

Out of the 353 heart tissue samples collected from red foxes, 9 (2.55\%; $95 \%$ CI: 1.25-4.96\%) were positive for DNA of Anaplasmataceae family. Specific amplification of all samples showed their positivity for A phagocytophilum-specific DNA. All samples were negative for $A$. platys or E. canis. A. phagocytophilum positive animals originated from 5 counties (Alba, $n=1$; Bihor, $n=2$;
Covasna, $n=3$; Hunedoara, $n=1$; Satu Mare, $n=2$ ) (Fig. 1). No significant differences were observed between counties regarding the prevalence of $A$. phagocytophilum.

All sequences obtained from positive samples were identical to each other. The sequence was found to be $99 \%$ identical to $A$. phagocytophilum strains.

Out of all samples, 5 (1.42\%; $95 \%$ CI: 0.52-3.47 \%) were positive for B. burgdorferi s.l. The sequenced rrf-rrs gene highlighted $98 \%$ and $100 \%$ similarities with $B$. burgdorferi sensu stricto (s.s.) and $B$. afzelii respectively.

Four samples (1.13 \%; 95 \% CI: 0.36-3.08 \%) from Covasna $(n=2)$, Bihor $(n=1)$ and Călărași $(n=1)$ counties were infected with $B$. afzelii. One sample from Cluj $(0.28 \%$; 95 \% CI: $0.01-1.82 \%)$ was infected with $B$. burgdorferi s.s. (Fig. 1).

No co-infections were found.

\section{Discussion}

Red foxes are among the most widespread and abundant wild carnivores. Their adaptation to urban environment and human presence, their frequent exposure to tick bites and the reservoir or maintenance host role for humans and domestic animals pathogens, highlight their importance for public health. However, no data concerning the epidemiology of tick-borne diseases in red foxes in Romania are available. To our knowledge, this is the first study investigating tick-borne pathogens in tissue samples collected from red foxes in Romania.

In Europe the information about the prevalence of $A$. phagocytophilum in foxes is scarce: Recorded prevalence range from $16.6 \%$ in Italy [12], $8.2 \%$ in Germany [13], $4 \%$ in Czech Republic [14] to $2.7 \%$ in Poland [15]. No positive foxes were found in studies conducted in Austria [1] or Bosnia and Herzegovina [16].

Few data regarding the prevalence of $A$. phagocytophilum in $I$. ricinus collected from foxes are available. In a recent study, Dumitrache et al. [17] found a prevalence of $4.4 \%$ of the pathogen in I. ricinus collected from red foxes in Romania. In a similar study conducted in Hungary, the prevalence was $1.3 \%$ [18].

Few data are available regarding the prevalence of $B$. burgdorferi s.l. in red foxes in Europe. In Germany, $24 \%$ of the skin samples from foxes were PCR positive after cultivation [19]. In another study from Germany the prevalence in skin samples was $7 \%$ following skin biopsy analysis [20]. However, a review on European reservoir hosts for $B$. burgdorferi s.l. suggests that red fox may be considered as a potential reservoir [2].

In Romania, foxes harbor I. ricinus, I. hexagonus, $I$. crenulatus and Dermacentor marginatus [21]. In Europe, I. ricinus is considered the main vector for both $B$. burgdorferi s.l. and A. phagocytophilum. Moreover, vectorial role of $I$. hexagonus for B. burgdorferi was also demonstrated [22]. Although A. phagocytophilum has been 
detected in engorged $I$. hexagonus, the vector competence of this tick species needs to be further investigated [23].

Although no co-infections with $A$. phagocytophilum and $B$. burgdorferi were found, our results showed that both pathogens are present in red foxes from the same counties (Bihor and Covasna), creating suitable epidemiological backgrounds for co-transmission. The role of red foxes in the ecoepidemiology of Lyme disease has not been completely elucidated. Older publications suggest that red foxes may serve as reservoir hosts $[19,20]$. In addition, Kahl et al. demonstrated the transmission of the pathogen from experimentally infected red foxes to I. ricinus ticks [24]. The information regarding the role of red foxes in the life cycle of $A$. phagocytophilum is similarly scarce [1].

\section{Conclusions}

To the best of our knowledge, A. phagocytophilum and B. burgdorferi were detected for the first time in tissues samples collected from red foxes in Romania. Our results indicate that foxes may be involved in the ecoepidemiology of these two pathogens by maintaining the infection in the synanthropic environments, posing an important risk for public health.

\section{Competing interests}

Financial competing interests

The authors declare that they have no competing interests.

Non-financial competing interests

There are no non-financial competing interests.

\section{Authors' contributions}

MOD wrote the manuscript and performed animals necropsy. IAM and AMI performed molecular diagnosis of Anaplasma phagocytophilum and animals necropsy. KZ performed the DNA extraction and molecular diagnosis of Borrelia burgdorferi s.l. SSB, DTI: manage foxes collection and transportation. GD, CMG performed animals necropsy. ADM coordinated the research team. All authors read and approved the final manuscript.

\begin{abstract}
Acknowledgements
MOD's work was financed by POSDRU grant no. 159/1.5/S/136893 grant with title: "Parteneriat strategic pentru creșterea calității cercetării științifice din universitățile medicale prin acordarea de burse doctorale și postdoctorale DocMed.Net_2.0". The research was supported from grant IDEI PCE 236/2011. MOD, IAM, AMI, GD, CMG, ADM are members of the COST Action TD1303. We would also like to thank the Local Sanitary Veterinary and Food Safety Authority for providing the red foxes, Cristina llea for providing English language correction and to Miruna Oltean, Anamaria loana Paștiu and Raluca Gavrea for helping with animals necropsy.
\end{abstract}

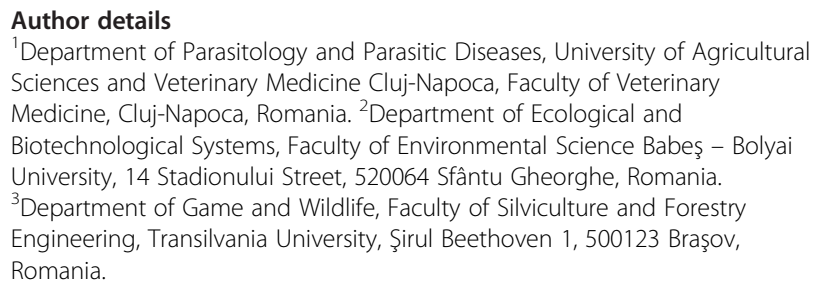

Received: 1 August 2015 Accepted: 1 October 2015

Published online: 08 October 2015

\section{References}

1. Duscher GG, Fuehrer HP, Kübber Heiss A. Fox on the run-molecular surveillance of fox blood and tissue for the occurrence of tick-borne pathogens in Austria. Parasit Vector. 2014;7:521.

2. Gern L, Estrada Peña A, Frandsen F, Gray JS, Jaenson TGT, Jonegan F, et al. European reservoir host of Borrelia burgdorferi sensu lato. Zent bl Bakteriol. 1998;287:196-204.

3. Martínez-Carrasco C, Ruiz de Ybáñez MR, Sagarminaga JL, Garijo MM, Moreno F, Acosta I, et al. Parasites of red fox (Vulpes vulpes Linnaeus, 1758) in Murcia, Southeast Spain. Rev Med Vet. 2007;7(158):331-5.

4. Baneth G. Tick-borne infections of animals and humans: a common ground. Int J Parasitol. 2014;44(9):591-6.

5. Rizzoli A, Silaghi C, Obiegala A, Rudolf I, Hubálek Z, Földvári G, et al. Ixodes ricinus and Its Transmitted Pathogens in Urban and Peri-Urban Areas in Europe: New Hazards and Relevance for Public Health. Front Public Health. 2014;2:251.

6. Mihalca AD, Gherman CM, Magdaş C, Dumitrache MO, Györke A, Sándor AD, et al. Ixodes ricinus is the dominant questing tick in forest habitats in Romania: the results from a countrywide dragging campaign. Exp Appl Acarol. 2012;58(2):175-82.

7. Parola P, Roux V, Camicas JL, Baradji I, Brouqui P, Raoult D. Detection of Ehrlichiae in African ticks by PCR. Trans R Soc Trop Med Hyg. 2000;94:707-8.

8. Walls JJ, Caturegil P, Bakken JS, Asanovich KM, Dumler JS. Improved sensitivity of PCR for diagnosis of human granulocytic ehrlichiosis using epank1 genes of Ehrlichia phagocytophila group ehrlichiae. J Clin Microbiol. 2000;38:354-6.

9. Murphy GL, Ewing SA, Whitworth LC, Fox JC, Kocan AA. A molecular and serologic survey of Ehrlichia canis, E. chaffeensis, and E. ewingii in dogs and ticks from Oklahoma. Vet Parasitol. 1998;79:325-39.

10. Warner CK, Dawson JE. Genus- and species-level identification of Ehrlichia species by PCR and sequencing. In: Persing DH, editor. PCR protocols for emerging infectious diseases. Washington, DC: ASM Press; 1996. p. 100-5.

11. Postic D, Assous MV, Grimont PA, Baranton G. Diversity of Borrelia burgdorferi sensu lato evidenced by restriction fragment length polymorphism of rif (5S)-rrl(23S) intergenic spacer amplicons. Int J Syst Bacteriol. 1994;44(4):743-52.

12. Ebani W, Verin R, Fratini F, Poli A, Cerri D. Molecular survey of Anaplasma phagocytophilum and Ehrlichia canis in red foxes (Vulpes vulpes) from central Italy. J Wildl Dis. 2011:47(3):699-703.

13. Härtwig V, von Loewenich FD, Schultze C, Straubinger RK, Daugschies A, Dyachenko V. Detection of Anaplasma phagocytophilum in red foxes (Vulpes vulpes) and raccoon dogs (Nyctereutes procynoides) from Brandenburg, Germany. Ticks Tick Borne Dis. 2014;5:277-80.

14. Hulínská D, Langrová K, Pejcoch M, Pavlásek I. Detection of Anaplasma phagocytophilum in animals by real-time polymerase chain reaction. APMIS. 2004;112(4-5):239-47.

15. Karbowiak G, Vichova B, Majlathova V, Hapunik J, Petko B. Anaplasma phagocytophilum infection of red foxes (Vulpes vulpes). Ann Agric Environ Med. 2009;16(2):299-300.

16. Hodžić A, Alić A, Fuehrer HP, Harl J, Wille-Piazzai W, Duscher GG. A molecular survey of vector-borne pathogens in red foxes (Vulpes vulpes) from Bosnia and Herzegovina. Parasit Vectors. 2015;8:88.

17. Dumitrache MO, D'amico G, Gherman CM, Matei IA, lonică AM, Paştiu Al, et al: Prevalence of Anaplasma phagocytophilum and Borrelia burgdorferi sensu lato, in Ixodes ricinus Parasitising on Red Foxes (Vulpes vulpes) from Romania. Bull UASMV Vet Med. 2015;72(1):134-37.

18. Sréter T, Sréter-Lancz Z, Széll Z, Kálmán D. Anaplasma phagocytophilum: an emerging tick-borne pathogen in Hungary and Central Eastern Europe. Ann Trop Med Parasitol. 2004;98(4):401-5.

19. Liebisch G, Dimpfl B, Finkbeiner-Weber B, Liebisch A, Frosch M. The red fox (Vulpes vulpes) a reservoir competent host for for Borrelia burgdorferi sensu lato. In: Proc 2nd Int Conf Tick-Host-Pathogen Interactions. 1995. p. 238.

20. Heidrich J, Schönberg A, Steuber S, Nöckler K, Schulze P, Voigt WP, et al. Investigation of skin samples from red foxes (Vulpes vulpes) in eastern Brandenburg (Germany) for the detection of Borrelia burgdorferi s. I. Zentralbl Bakteriol. 1999;289(5-7):666-72.

21. Mihalca AD, Dumitrache MO, Magdaş C, Gherman CM, Domşa C, Mircean V, et al. Synopsis of the hard ticks (Acari: Ixodidae) of Romania with update on host associations and geographical distribution. Exp Appl Acarol. 2012;58(2):183-206.

22. Gern L, Toutoungi LN, Hu CM, Aeschlimann A. Ixodes (Pholeoixodes) hexagonus, an efficient vector of Borrelia burgdorferi in the laboratory. Med Vet Entomol. 1991;5(4):431-5. 
23. Stuen S, Granquist EG, Silaghi C. Anaplasma phagocytophilum-a widespread multi-host pathogen with highly adaptive strategies. Front Cell Infect Microbiol. 2013;22(3):31.

24. Kahl O, Geue L. Laboratory study on the possible role of the European fox, Vulpes vulpes as potential reservoir of Borrelia burgdorferi s.l. In: Proc 2nd Int Conf Tick-Host-Pathogen Interactions. 1995. p. 239.

Submit your next manuscript to BioMed Central and take full advantage of:

- Convenient online submission

- Thorough peer review

- No space constraints or color figure charges

- Immediate publication on acceptance

- Inclusion in PubMed, CAS, Scopus and Google Scholar

- Research which is freely available for redistribution 